\title{
Fibrous histiocytoma of the nose in an 8-year-old girl
}

\author{
Gargi Pandey, Kiran Varadharajan, Sevasti Konstantinidou, Benjamin Hartley
}

ENT, Great Ormond Street Hospital for Children NHS Trust, London, UK

\section{Correspondence to} Dr Gargi Pandey; gargi.pandey@nhs.net

Accepted 11 April 2021

\section{DESCRIPTION}

A fit and well 8-year-old girl was referred to a tertiary paediatric centre due to a slow growing swelling around the nasal dorsum. Examination revealed no skin changes or pits and she reported no associated nasal symptoms. At her local district general hospital, a differential diagnosis of a possible nasal dermoid was made, however, a subsequently organised MRI scan suggested an extra nasal glioma. She had a biopsy of the lesion at the tertiary centre which was in keeping with non-langerhans histiocytosis. After a multidisciplinary discussion and CT imaging (figure 1) to aid surgical planning, the patient proceeded for excision of the nonmalignant tumour via a Lynch Howarth incision. The final histology concluded a benign fibrous histiocytoma (BFH) (figure 2).

$\mathrm{BFH}$ is known to occur in the skin and deep soft tissues of the extremities and retroperitoneum. ${ }^{1}$ Most frequently BFH is found in sun exposed areas of the skin or can be associated with areas of trauma or recurrent infections. ${ }^{2}$ Involvement of the nose is rare; less than five cases have been found in children, all symptomatic. ${ }^{1-4}$ Our patient was asymptomatic, only presenting due to a nasal swelling. $\mathrm{BFH}$ is usually a painless and slow growing mass with symptoms secondary to the invasion of anatomy around it. Differential diagnoses for a child with a nasal swelling include nasal dermoid, glioma or meningoencephalocele. CT or MRI is warranted to delineate the anatomy but also intracranial connections. Management involves biopsy for definitive diagnosis and surgical

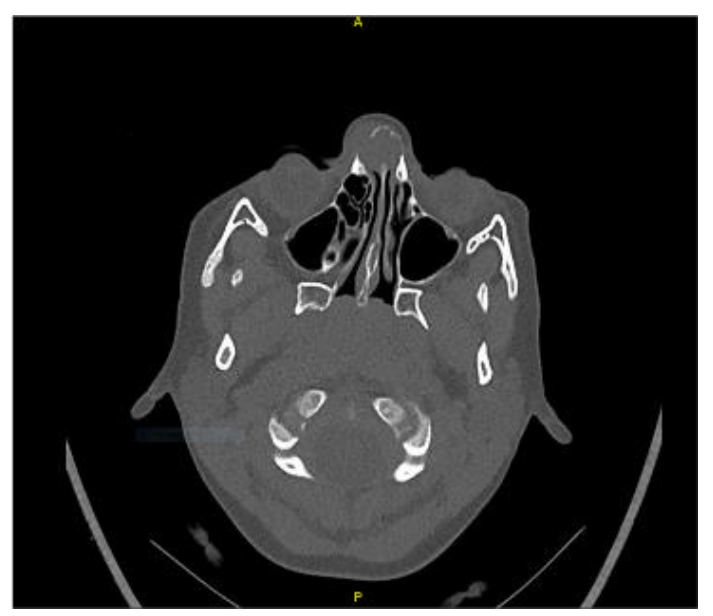

Figure $1 \mathrm{CT}$ showing a nasal lesion centred on the superior nasal dorsum, slightly right eccentric. It is causing partial erosion of adjacent nasal bones, nasal septum and right frontal sinus.

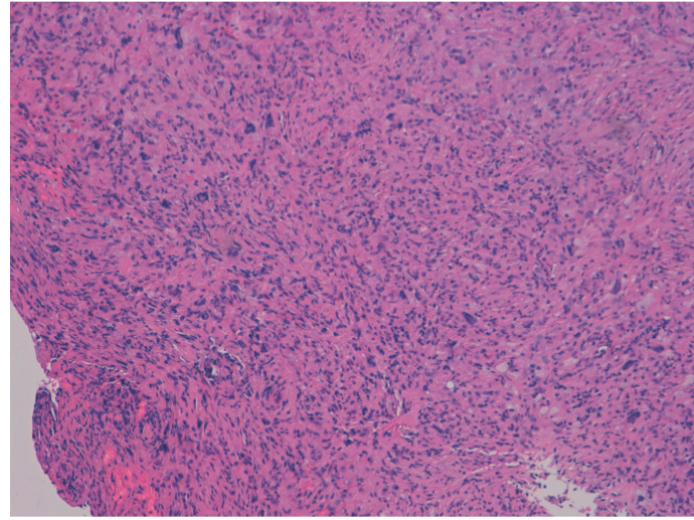

Figure $2 \quad H \& E$ stained section ( $\times 10$ magnification) showing spindled cells admixed with Touton-like giant cells and foamy macrophages.

excision in a tertiary paediatric hospital, with good long-term prognosis. There is also a role for chemotherapy. ${ }^{5}$ We opted for surgical excision. The patient's mother was made aware that if local recurrence were to occur then along with surgical management, chemotherapy would be reconsidered.

\section{Learning points}

- Fibrous histiocytoma should be added to this list of differentials for slow growing head and neck masses in children.

- CT and MRI are commonly done to aid surgical planning and further characterise the lesion for diagnosis.

- Management of malignant fibrous histiocytoma can include radiotherapy, chemotherapy and surgery, however, the mainstay of management for benign fibrous histiocytoma is surgical excision.

Acknowledgements We would like to thank Dr Mohammad Haini (Registrar in Paediatric Pathology) and Dr Thivya Sekar (Consultant Paediatric pathologist) for helping us with the pathology image and report.

Contributors GP is the main author of this manuscript. The case was identified by KV and is under the care of BH. SK was involved in the care of the patient. All listed authors were involved in the care of the patient, gave suggestions and reviewed the manuscript prior to submission.

Funding The authors have not declared a specific grant for this research from any funding agency in the public, commercial or not-for-profit sectors.

Competing interests None declared.

Patient consent for publication Obtained.

Provenance and peer review Not commissioned; externally peer reviewed. 
Images in...

\section{REFERENCES}

1 Shrier DA, Wang AR, Patel U, et al. Benign fibrous histiocytoma of the nasal cavity in a newborn: MR and CT findings. AJNR Am J Neuroradiol 1998;19:1166-8.

2 Shearer WT, Schreiner RL, Ward SP. Benign nasal tumor appearing as neonatal respiratory distress: first reported case of nasopharyngeal fibrous histiocytoma. Am J Dis Child 1973;126:238-41.
3 Rice DH, Batsakis JG, Headington JT, et al. Fibrous histiocytomas of the nose and paranasal sinuses. Arch Otolaryngo/ 1974;100:398-401.

4 Del-Rey E, De-La-Torre FE. Fibrous histiocytoma of the nasal cavity. Laryngoscope 1980:90:1686???1693-93.

5 Bielamowicz S, Dauer M, Chang B, et al. Noncutaneous benign fibrous histiocytoma of the head and neck. Otolaryngology - Head and Neck Surgery 1995;113:140-6.

Copyright 2021 BMJ Publishing Group. All rights reserved. For permission to reuse any of this content visit

https://www.bmj.com/company/products-services/rights-and-licensing/permissions/

BMJ Case Report Fellows may re-use this article for personal use and teaching without any further permission.

Become a Fellow of BMJ Case Reports today and you can:

- Submit as many cases as you like

Enjoy fast sympathetic peer review and rapid publication of accepted articles

- Access all the published articles

Re-use any of the published material for personal use and teaching without further permission

\section{Customer Service}

If you have any further queries about your subscription, please contact our customer services team on +44 (0) 2071111105 or via email at support@bmj.com.

Visit casereports.bmj.com for more articles like this and to become a Fellow 